\title{
Kinga Jasiak
}

Adam Mickiewicz University in Poznań (Poland)

\section{The International Monetary Fund's Role in Overcoming Economic Crisis in PIIGS}

\begin{abstract}
The financial crisis started in 2008 and touched the whole world but some countries experienced its consequences more than others. The European Union and in particular eurozone, slid into a stage of economic recession. Five of $28 \mathrm{EU}$ countries faced the edge of financial fall, named PIIGS - Portugal, Italy, Ireland, Greece and Spain. Multidimensionality of the global crisis have caused that international economic organizations faced a great challenge, For them it was a test of efficiency and effectiveness. The leading role in this period belonged to the International Monetary Fund (IMF), which is standing on the guard of the whole international currency system. The aim of the article is to draw and analyze the most important IMF activities towards PIIGS, especially what instruments were proposed as a help and what changes had to be made by receiving states in order to receive the financial support. The ten-year perspective taken in the article allows for the more comprehensive assessment of the issue.
\end{abstract}

Keywords: PIIGS; IMF; economic crisis; European Union

\section{Introduction}

A financial crisis started in $2008^{1}$ touched the whole world. Some countries experienced its consequences more than others. Although it is commonly considered financial, the crisis' results extended also to the other spheres of states' functioning and forced politicians to make often radical decisions. Initially "local" financial crisis became worldwide economic problem, leading to the hold-up of economic growth and even recession in many countries. Strong economic repercussions have been felt not only in the crisis epicenter - the United States - but also on its peripheries, countries hundreds miles away of it. With time Europe

1 In the body of scientific literature there are two dates considered as the crisis' beginning - 2007 and 2008. This article upholds the second of them, September 15, 2008, as at this day Lehman Brothers bank announced bankruptcy. 
also started to gradually fall into the crisis. EU countries felt the phantom of bankruptcy, mainly because of strong financial connections within European Union. Five of $28 \mathrm{EU}$ countries faced the edge of financial fall - the group of peripheral countries (Portugal, Italy, Ireland, Greece and Spain) with low budgets and high public debts, named PIIGS after the countries' initials. Initially the group counted four countries but in 2010 it was joined by another "I": Ireland. Some authors add also another "G" indicating Great Britain.

Multidimensionality of the global crisis have caused that international economic organizations faced a great challenge. For them it was a test of efficiency and effectiveness, because the countries that could not singlehandedly cope with the situation were forced to act transnationally. It seems that in this period the leading role belonged to the International Monetary Fund (IMF), considered as one of the key institutions for global economy, standing on the guard of the whole international currency system. The IMF tasks include advocating equitable economic growth, supporting and coordinating international currency cooperation, stabilizing currencies, supporting states (members) with funds in case of balance of payments issues (Domagała, 2004,p. 109-119). In the context of this article the key task of IMF is the latter concerning loans taken by states to improve their balance of payment.

The article's research problem concerns the role of the IMF in the last global economic crisis in certain group of countries. In respond to still growing controversies regarding the legitimacy of the IMF functioning, it seems to be justified to analyze its activities in one of the most difficult moments for the global economy in recent years. The ten-year perspective taken in the article allows for the more comprehensive assessment of the issue. In this article the historical method was applied to present both the situation of the countries being a part of the PIIGS group and the origins of the economic crisis that led them to the edge of bankruptcy. Additionally, the content analysis was used for analyzing documents published the IMF concerning help granted to the PIIGS group.

The aim of the article is to draw and analyze the most important IMF activities towards PIIGS. Also, it is important to investigate what instruments were proposed as a help and what changes had to be made by receiving states in order to receive the financial support. It must be stressed that only these activities which were and still are connected with mitigating the crisis' consequences in PIIGS were taken into account. The intended effect of the work is an answer to a question whether the IMF has shown activity in the area of assistance provided to the PIIGS group after 2008.

\section{The Crisis Origin}

The global financial crisis originates from the United States and resulted from the activities of both Federal Reserve and individual subjects. However, the events that have led to the break stem from 2001 when the Federal Reserve decreased interest rates after the attack on World Trade Center. That decision allowed banks to offer cheaper loans and encouraged people to take out numerous mortgages, therefore a "speculative bubble" was created. Analyzing 
the crisis origin it can be noted that initially the loans were given only to the people with solvency. However, when the market has been saturated, banks granted more subprime loans (Matysiak, 2017, p. 47) (loans for the people having difficulties with repaying) which have not been repaid because of the people's lack of proper accounting liquidity.

The transfer of the crisis to Europe was only the matter of time. Because of the globalization processes markets of many states are open and tightly connected, therefore the actions of one state may have an impact on another, even those in the opposite part of the globe - and that was exactly the case. On the one hand, the global financial market of states predicts the participation in the global economy even for the poorest and smallest countries, but on the other hand it makes them equally responsible for the mistakes of even the richest and most influential ones.

Speaking about European Union - because its member countries are the subjects of this article - it must be noted that it has established by treaties how do the states should conduct their fiscal policies. In the $126^{\text {th }}$ article of the Treaty on the Functioning of the European Union we find a provision that "Member States shall avoid excessive government deficits" which should be controlled by means of debt and budget deficit in relation to GDP (TFUE, art, 126). In the Protocol on the excessive deficit procedure annexed to the Treaty there were appointed particular values of deficit and public debt for the member states. According to it, the deficit and debt should not exceed 3\% and 60\% of GDP, respectively, and the control over them should belong to the European Commission and be based on submitted reports. ${ }^{2}$

\section{PIIGS Situation Before and During the Crisis}

The states of European Union experienced various extents of the crisis' results, but Portugal, Italy, Ireland, Greece and Spain noted the biggest decrease in GDP and increase in debt and deficit. In 2007-2013, in contrast to 2007, GDP of these countries decreased by $5 \%$ in Spain, $5,1 \%$ in Italy, 5,3\% in Ireland, 6,2\% in Portugal and 22,6\% in Greece, while in the same time the whole Eurozone noted 0,9\% decrease. These numbers show that the PIIGS group felt the crisis definitely more than the Eurozone (Piętak, 2015, p. 71). The same thing happened to employment rates.

Portugal. Portugal has been dealing with financial issues for a very long time. Decrease in GDP was observable yet in 1997. Moreover, worsening accounts balances and budget deficit placed Portugal low in the ranks of economic competitiveness (The euro crisis. A second...2011) but it was entering the Eurozone which caused that Portugal experienced the edge of bankruptcy. Portugal had a big problem with adjusting national economy to the richer economies of other EU member states. After the adoption of Euro, salaries started to increase more than labor performance. Additionally, Portugal had a low development capability of new technologies sector and generating knowledge. Fiscal policy aimed at

2 Protocol 12 on the excessive deficit procedure. 
fighting the debt depended on increasing state incomes, however, lowering outcomes were not considered. Portuguese were taking more loans without having further capability to repay them. Beside macroeconomic problems, the country was devastated by a flood. The estimated cost of losses was 1 billion Euro.

Ireland. For many years (before the crisis) it was praised for fast economic growth. Practically nothing indicated that the crisis will reach states in which unemployment was low and companies were paying employees increasing salaries. It is worth to mention that a number of international companies had branches in Ireland which made them more vulnerable to the crisis. The country fall into the debt trap mainly because of strongly developed construction market, which was also the cause of Ireland's fast economic development. The market saturation was the reason why developers stopped repaying loans and fired employees. Because of the oversupply real estates' prices increased significantly. For example, in 1996-2006 the prices of houses increased two or even three times (Michalski, 2014, p. 10). Unemployment started to grow, tax income lowered and so was GDP. Another national bank system did not work properly.

Italy. Italian economy had a 3rd place among EU economies, but it was developing slower than assumed, so it may be boldly stated that it faced stagnation. With increased unemployment public debt exceeded 1,7 trillion Euro in 2010 (115\% of GDP) (Górniewicz, 2011, p. 455). It is indicated that the source of bad macroeconomic results was invalid labor law, financial sector inefficiency and basing economy on small enterprises unable to compete with bigger companies on the international market. In comparison with other countries from the PIIGS group Italy had a healthy bank system. The country's biggest drawback was non-competitive economy in the Eurozone. Similarly to Portugal, salaries increased while labor performance stagnated.

Greece. The economic situation of Greece right before joining the Eurozone was not good - it had a low competitive position on the international arena. Moreover, adopting Euro itself - as it turned out later - was performed without the proper economic preparation of the state. Additionally Greece only temporarily fulfilled the terms of convergence, which are to verify whether a state joining the Eurozone will be able to function in it without distortions. Greece's credibility decreased even further when it turned out that its budget deficit is not 3,7\% of GDP (April 2009) but 13,6\% (April 2010). ${ }^{3}$ The state's solvency was dropping dramatically as well as the prices of Greek assets.

Spain. In this case the problem concerned mainly incomes. Even a half of tax income was connected with real estate market based on the speculative bubble. The situation was analogical to the one in the United States where the inflated speculative bubble on the real estate market has burst. It is indicated that in 2006-2007 in Spain more houses

3 Greek government gave false statistical data concerning deficit, debt and inflation. Data revision was made by Jeoris Papandreu's government only a year later, drawing the attention of international audience to the possibility of Greek economy collapse. 
were built than in France and Germany together, and the value of real estate market investments exceeded 33\% of GDP. Moreover, in 2009 there were 23 flats per 16 families (Żemła, 2012, p. 40). The crisis has struck hard in the young generation of Spaniards because unemployment indicator among them was the highest. Besides, high public debt (ca. 120\% of GDP) and difficulties within the bank sector caused that Spain ended up in the PIIGS group.

\section{IMF Instruments Applied to Improve PIIGS Financial Situation}

The IMF is a specialized UN's agenda founded with its own statute, structure and budget. It was created in 1945 and focuses 189 states since (The IMF at a glance, 2018). Among statute aims are: promoting international currency cooperation, assuring financial stability and facilitating international commerce, promoting economic growth and decreasing global poverty.

According with the IMF statute, the organization is obliged to undertake operational actions to assure financial stability and security of member states (Chrabonszczewska, 2011), and this is why the IMF has actively engaged into help. There was launched a series of loan programmes aimed to help the states to stop the spreading crisis and its further negative consequences. As a result special IMF help programmes began to be implemented at risk endangered countries - the Supported Programmes or the other forms of direct help. It is worth to mention that IMF grants advisory, technical and consultative support, however, states usually ask for the financial help. In the scope of the crisis discussed in this article IMF has launched the following instruments:

- credit promises - SBA - Stand by Arrangements - considered the main supportive instrument, and the most often used so far. A state choosing this kind of support also participates in the costs, although they are not as high as in the case of using the help from individual sources

- EFF-Extended Fund Facility - it is a medium-term support of institutions' helping programmes

- FCL - Flexible Credit Line - an instrument predicted in case of crisis and designed for countries with properly functioning economy, stable economic policy and high financial credibility. It is indeed an instrument that may protect against possible crisis

- PLL - Precautionary and Liquidity Line - this instrument is offered to countries with quit stable economic foundations but do not qualify for receiving help within FCL. It is granted for six months, sometimes even for two years

- RFI - Rapid Financing Instrument - designed for countries requiring urgent financial support

Moreover, in the poorest countries the IMF were implementing preventive programmes not requiring paying interest for available resources (Wróblewski, 2014). 
Portugal. According to the actual data on the official IMF website, in June $30^{\text {th }}, 2018$ Portugal had loans from the IMF around 3,86 billion Euro.

After the global crisis started, Portugal as one of the countries mostly endangered by bankruptcy in the Eurozone in May 17, 2011 applied to the IMF for financial support. The money supposed to help it to conduct a structural reform assuming the economic growth and a fiscal reform to achieve financial stability. In the official document to the IMF Portuguese authorities asked for granting Extended Fund Facility (EFF) for another 3 years. The funding supposed to be the supplement to help granted by the European Union. Portugal applied for 26 billion Euro while the total amount needed by the country to quit its financial problems was 78 billion Euro. The meeting of interested parties took place in May 2011 and was participated by Portuguese Minister of Finances, Bank Governor and other Ministers. The IMF representatives met also with the employees of private banks, think tanks and the unions.

Granting a financial help by the IMF obliges countries to introduce particular changes in various sectors. In case of Portugal the basic condition for paying another parts of money was the gradual lowering budget deficit and the stabilization of public debt. There were established certain goals to achieve - lowering the deficit to 4,5\% of GDP in 2011 and 3\% until 2013. Initially the help programme was based mainly on the internal fiscal devaluation that supposed to be achieved through the rationalization of salaries. At the next stages there were implemented bigger structural reforms: the reform of labor market (e.g. labor agreements were changed and the employment chances of young people were increased), the liberalization of non-tradable commodities and services sector, the privatization of enterprises and judicial reform (Portugal: request for a...2011), . These changes, together with the financial help, supposed to help Portugal escape the phantom of economic collapse.

May $17^{\text {th }}, 2014$ Lisbon announced that finishes the three year help programme. EU and the IMF inspectors positively assessed Portugal's credit agreement execution.

The last summary statement within annual overview (so-called IMF's statute Art. IV overview) prepared after the visit of the IMF's representatives in Portugal between $15^{\text {th }}$ and $29^{\text {th }}$ May 2018 concludes that the situation in Portugal has been stabilized, ${ }^{4}$ although the stable growth is necessary for it in order to equalize the living conditions with other European countries. Employment rates increase, public debt decreases and there is a visible improvement of financial stability.

4 In 2017 was recorded 2,7\% GDP growth mainly due to investments and commodities and services export, and especially due to tourism. In March 2018 unemployment rates lowered to the level of 7,4\%. There are emerging difficulties with staffing job positions requiring higher qualifications. The increase of salaries was maintained in 2017 while the minimal wages were increased to $22 \%$ of all earning people (in 2016 it was $20,6 \%$ ). 
Ireland. Ireland has received the financial support with a stipulation that it was granted because of ,the securitization of financial stability in the European Union and Eurozone”. The program was attended, despite the IMF, by European Central Bank and the European Commission.

In the scope of EFF the IMF predicted 22,5 billion Euro in total. The total support amount for Ireland (including EU's institutions) was 85 billion Euro per three years. The programme that has been proposed as the part of the loan aimed to cure the banking system. Moreover, another aim was to restore trust and financial stability. The packet consisted of the plans of thorough Irish banking system restructuration and public finances protection. Additionally, there was predicted a reform aimed to restore a long-term potential of Irish economy growth.

In the scope of the programme there were assumed three main goals of helping packet: the identification of profitable banks and the restoration of their stability through the employment reduction and reorganization, bank capital increase and strengthening bank supervising system.

The conditions that Ireland had to meet to receive another parts of money included the reorganization of banking system, the reduction of budget deficit, the reduction of social benefits and increase the taxes paid by enterprises.

In December 2013 the IMF transferred the last part of the loan for the Ireland.

Italy. In case of Italy help from the IMF was based mainly on advising and controlling the budget situation. The list of reforms needed for Italy to develop faster during the crisis could be found i.a. in the IMF's and OECD's publications. In their documentation on Italy there were i.a. recommendations concerning: the consolidation of public funds and the gradual decrease of public debt. The reduction of the deficit supposed to be conducted mainly through limiting public expenses. Simultaneously, the Italian authorities were given a task to simplify a complicated and ineffective tax system which was aimed to limit the avoiding of paying taxes by individuals and companies. Fixing the public finances could be supported also by the increase of regions' tax autonomy and the limitation of transfers scale from central to local authorities. Moreover, the Italian government was instructed that there is a necessity to decrease administrational barriers slowing entrepreneurship and limiting competition in many sectors.

Additionally, it was underlined that the Italian labor market requires reforms that should tend to make it more flexible and to decrease differences between overly protected people hired for an indefinite period and insufficiently protected people hired for a definite period.

Among the other recommendations of international organizations we can mention also privatization, reforming universities and the reform of provisions on environmental protection.

Greece. The current amount of loans taken by Greece from the IMF is 8,91 billion Euro (checked at June 30, 2018). 
Greece as the country among the PIIGS group that have suffered the most from the crisis was offered a very high loan of 110 billion Euro, from which 80 billion were given by the EU countries (30 billion in 2010) and 30 billion by the IMF ( 15 billion in 2010).

The IMF helped Greece within credit promise Stand by arrangement (SBA). In return for the funds, Greece obliged itself to implement a programme that supposed to restore its economy condition. The main goal of the programme was to correct fiscal imbalance and to restore investors' trust to the Greek economy. The lack of this trust was connected with disclosing the false data concerning the scale of budget deficit. Starting from 2013 the programme strategy was based mainly on lowering the loan to GDP indicator and on decreasing the deficit in the local government and governmental institutions sectors to the level below 3\% of GDP until 2014. Moreover, the state's expenses were lowered much below 7\% of GDP until 2013.

Beside the fiscal reforms concerning the budget there were implemented changes in the majority of state functioning spheres: retirement reform, health sector reform and tax reform.

In general, Greece received from the EU countries and from the IMF three help packets - first in 2010 and 110 billion Euro, second in 2012: 130 billion Euro and third in 2015: 86 billion Euro. In August 2018 Greece have accomplished the third help programme.

In 2017 Greece asked the IMF for another 1,6 billion Euro loan. The IMF agreed to grant it under the condition that the Greek government will negotiate the loan reduction (in the form of interests decrease) with the EU countries. Greek authorities also obliged to maintain the primary surplus in the budget at 3,5\% of GDP (which means without the costs of debt maintenance) until 2022 and later. Then, Greece shall assure that its fiscal obligations "will follow the EU framework".

Spain. Similarly to the Italian case, the IMF role was limited mainly to giving recommendations. During the first waves of the crisis, Spaniards tried to overcome the crisis on their own and this is why governmental expenditures increased while the taxes were decreased. Unfortunately, it has led to the increase of deficit. Then, the government tried to reduce the public investments which caused the desired effect - the limitation of budget deficit. Employment was reduced. The Spanish economy has recovered the external balance due to the diversification of commerce with more developed countries but also due to the competitiveness increase which resulted in reductions of individual labor costs and salaries. The internal balance has been achieved through the limitation of net indebtedness by the private sector in which the balance of savings and investments in 2013 took positive values.

Considering the IMF activity toward Spain during the crisis, we need to mention that in October 2012 the IMF delegation started 10-day visit in Spain based on which they

5 The term of repaying the second loan has been prolonged by 10 years (now it is 2033 instead of 2023). 
prepared a report on the condition of Spanish financial system. It was a routine visit which was connected with a loan that Euroland supposed to grant Spain for the healing of banking system. Creating such a report is one of the conditions for granting the loan for Spanish banks. Spain received a financial help from the European Union for recapitalization of Spanish financial institutions from the European Financial Stability Facility (EFSF) in the amount of 538 billion Euro.

\section{Summary}

The above considerations clearly prove that the IMF actively participated in overcoming the results of economic crisis in the PIIGS group. For some of them (Portugal, Greece and Ireland) was granted direct help in the form of loans and for the others (Italy, Spain) indirect forms of help were proposed such as sharing expert knowledge on budget policy with the countries' authorities.

In each of the described cases we were dealing with the cooperation of the European Union's and the IMF's institutions with the countries interested with their help. Such a situation in which three political actors are engaged is highly complicated. Assessing the IMF activity we need to admit that this organization was not prepared neither organizationally nor financially for implementing help programmes in the countries that have had developed economies. The IMF has never lent to the Eurozone countries before and this is why the consequence was the implementation of programmes that were not completely adequate to the PIIGS group specifics and economic situation. This is one of the most often accusations toward the IMF - that it does not adjust help programmes to the economic situation of a given country and always uses a similar tactic depending on austerities and other fiscal policy limitations.

Analyzing the situation of the PIIGS group ten years after the global economic crisis outbreak we can discern that Portugal succeeded in restoring its economy, achieving the 2,7\% growth of GDP in 2016, which is a score unseen in that country for at least 17 years. Ireland was the country stricken in chaos but has become one of the fastest growing economies in Europe. In Italy the situation also has been stabilized though in 2018 the country has drawn the EU's attention again. Unfortunately, after years of implementing reforms for overcoming the crisis results, Italians decided to turn away from the European Union and follow another path. All of that is connected with the change of ruling party that demands greater fiscal freedom from the EU's institutions. Greece has noted the increase of growth dynamics from 2017. It is indicated that it happened mainly due to the loans granted by the IMF and the EU institutions. However, the greatest benefits have been brought to Greeks by the changes proposed and implemented under these institutions' supervision. ${ }^{6}$ Spanish economy has been restored to the condition from before the crisis and it has noted the annual growth of

6 Making labor market more flexible (the liberalization of provisions on minimal wage and the 
$2-3 \%$ of GDP for the last four years. Additionally, Spanish citizens are getting richer due to the dynamically developing tourism sector.

Despite huge controversies connected with the IMF activity it should be stated that its programme has been realized and its goals have been achieved. The countries with severe budget condition - PIIGS - have quit the crisis. Eventually, the IMF benefited from the situation, elaborated the new helping scenario for developed countries (not only for developing ones) participating in the process of economic integration. Their economic situation remains in strict dependency on the situation and decisions within the economic policy of the whole organization. Ultimately, the new framework of cooperation with political and financial institutions on the regional and transregional level has been developed.

\section{References}

Bank of International Settlements. (2018). Promoting global monetary and financial stability. Annual Economic Report.

Chrabonszczewska, E. (2011). Międzynarodowy Fundusz Walutowy. In Kompendium wiedzy o organizacjach międzynarodowych. E. Łaźniewska (Ed.). Warsaw: Wydawnictwo Naukowe PWN.

Dziennik Urzędowy Unii Europejskiej, Traktat o Funkcjonowaniu Unii Europejskiej. Retrieved from: https://eur-lex.europa.eu/resource.html?uri=cellar:2bf140bf-a3f8-4ab2-b506fd71826e6da6.0009.02/ DOC_2\&format=PDF.

Dziennik Urzędowy Unii Europejskiej, Protokoty. Retrieved from: https://eur-lex.europa.eu/resource. html?uri=cellar:2bf140bf-a3f8-4ab2-b506-fd71826e6da6.0009.02/DOC_3\&format=PDF.

Piętakm, Ł. (2015). Kryzys w Hiszpanii w latach 2008-2013. Ekonomia XXI wieku, vol. 2, No. 6.

Górniewicz, G. (2011). Kryzys finansów publicznych w krajach grupy PIIGS. Zeszyty Naukowe Uniwersytetu Szczecińskiego, No. 686.

International Monetary Fund. (2012). 2012 article IV consultation with Italy -concluding statement of the IMF mission. IMF Country Report No.12/181.

International Monetary Fund. (2015). Crisis program review.

International Monetary Fund. (2009). Euro Area Policies: 2009 Article IV Consultation-Staff Report; Public Information Notice on the Executive Board Discussion; and Statement by the Executive Director for Member Countries. IMF Country Report No. 09/223.

International Monetary Fund. (2010, December 16). IMF Survey: IMF Approves €22,5 Billion Loan For Ireland.

International Monetary Fund. (2011). Portugal: Request for a Three-Year Arrangement Under the Extended Fund Facility. IMF Country Report No. 11/127, June.

International Monetary Fund. (2018, May 29). Portugal: Staff Concluding Statement of the 2018 Article IV Mission.

International Monetary Fund. (2012, July 27). Public information notice: IMF Executive board concludes 2012 article IV consultation with Spain.

facilitation of making periodical labor agreements), reducing employment (about 100000 people), the reduction of salaries in the public sector and the privatization of state energy enterprises. 
Kowanda, C. (2010). Państwa-ofiary kryzysu strefy Euro. Świńska grypa II. Polityka, No. 51 (2787).

Latoszek, E., Proczek, M. (2013). Polityka rozwojowa. Rola organizacji międzynarodowych $w$ zwalczaniu ubóstwa na świecie. Warsaw: Oficyna Wydawnicza Szkoła Głowna Handlowa.

Łaźniewska, E. (2011). Kompendium wiedzy o organizacjach międzynarodowych, Warsaw: Wydawnictwo Naukowe PWN. Łoś-Nowak, T. (2004). Organizacje międzynarodowe w stosunkach międzynarodowych. Istota, mechanizmy działania, zasieg. Warsaw.

Matysiak, P. (2017). Pomoc finansowa dla krajów strefy euro podjęta w reakcji na kryzys zadłużenia. Gospodarka w Praktyce i Teorii, No. 46.

Michalski, B. (2014). Kryzys irlandzki. Jak i dlaczego celtycki tygrys stracił swoją drapieżność? In Kryzys i perspektywy strefy euro. J. Rymarczyk, M. Wróblewski, D. Brzęczek-Nester (Eds.). Wrocław.

Ministerstwo Finansów, Biuro Pełnomocnika Rządu ds. wprowadzenia euro przez Rzeczpospolitą Polską. (2010). Kryzys grecki -geneza i konsekwencje. Warsaw.

Rymarczyk, J., Wróblewski, M., Brzęczek-Nester, D. (2014). Kryzys i perspektywy strefy euro. Wrocław. Szajowska, B. (2012). Kryzys grecki i drogi jego rozwiązania. Ekonomia międzynarodowa, No. 3.

The Economist. (2011, January 16). The euro crisis. A second wave (Briefing after The euro area debt crisis).

The IMF at a glance. (2018). Retrieved from: http://www.imf.org/en/About/Factsheets/IMF-at-a-Glance.

Treaty on the Functioning of the European Union. Article 126. Retrieved from: https://eur-lex.europa. $\mathrm{eu} /$ legal-content/EN/TXT/PDF/?uri=CELEX:12012E/TXT\&from=EN.

Walkowski, M. (2012). Europa w kryzysie: perspektywy gospodarcze Unii Europejskiej do 2020 roku w kontekście problemów rozwojowych państw grupy PIIGS. Przegląd Politologiczny, No. 1/2012.

Wróblewski, M. (2014). Aktywność pożyczkowa MFW wobec globalnego kryzysu finansowego. In Kryzys i perspektywy strefy euro. J. Rymarczyk, M. Wróblewski, D. Brzęczek-Nester (Eds.). Wrocław.

Żemła, M. (2012). Atrakcyjność turystyczna, bańka spekulacyjna i kryzys gospodarczy - próba analizy wzajemnych relacji na przykładzie Hiszpanii. International Journal of Management and Economics, No. 35 .

\section{Author}

\section{Kinga Jasiak}

MA, kinga.jasiak@amu.edu.pl - Adam Mickiewicz University in Poznań, Faculty of Political Science and Journalism 